\title{
Measuring Innovative Employee Behavior in an Enterprise - Methodological Aspects
}

\author{
Joanna Wyrwa ${ }^{1}$, Ph.D.
}

\begin{abstract}
Innovativeness is currently one of the basic determinants of development and building competitiveness in modern organizations. It is conditioned by a number of factors, among which an important group are internal factors related to the activity and participation of employees in the generation, development and implementation of innovative ideas, among other things. Modern enterprises cannot limit themselves to active adaptation, but should themselves become innovative organizations characterized by skillfulness in creating, implementing and disseminating innovations. The aim of the study is to present the concept of measuring innovative employee behavior in the internal perspective of the organization. The article discusses the main methodological problems regarding the employee innovation measurement model. The implementation of the objective required reviewing the literature and developing an independent research model. The novel nature of the issues raised, together with the high relevance of the research problem at hand, prompted the need to pay special attention to the correct design of the research process. As the literature indicates, decisions made at the design stage of research, and further diligence in implementing those decisions, determine not only the quality of the research project itself, but more than anything, the credibility of the conclusions drawn on their basis.
\end{abstract}

Keywords: innovative behaviours, employee behaviours, stimulate innovations, research methods, scientific research

\section{Introduction}

In the era of increasing competition, companies are making efforts to become more competitive, also by increasing innovation, understood as the ability to implement new solutions in various areas of business operation. To this end, many organizations are seeking new sources of innovation that will stimulate and promote employee behavior beyond the traditional standards of task performance and achieved results. The importance of - and need for - proactive behavior among employees is stressed, which not only allows adaptation to changes, but also involves generating and implementing new solutions. Innovative employee behavior is considered key in ensuring the increase of the company's efficiency and survival (Nederveen Pieterse, van Knippenberg, 
Schippers, Stam, 2010), as well as its competitiveness (Ployhart, 2015). Arguments pointing to the need for innovative behavior in employees, which makes the organization perform better, are cited by various researchers in this field (Sameer, 2018; Turek, Wojtczuk-Turek, 2017; Bratnicka, Ingram, WronkaPośpiech, 2016; Ingram, 2016; Kraśnicka, 2016; Kraśnicka, Ingram, 2016; Głód, Kraśnicka, 2015; Kraśnicka, Głód, 2015; Ingram, Głód, 2014; Kraśnicka, Wronka-Pośpiech, 2014; Krot, 2014; Gableta, Bodak, 2014; Kheng, June, Mahmood, 2013; Kheng, Mahmood, Hamy Beris, 2013; Wojtczuk-Turek, 2012; Odoardi, Battistelli, Montani, 2010; Yuan, Woodman, 2010; Janssen, 2005; Janssen, 2003; Scott, Bruce, 1994).

Literature review indicates that innovativeness is associated mainly with technological processes, new or improved products, and organizational changes occurring in the company that tend to be situated in the context of changes in technology. The role of man, and their capabilities and psychological limitations, are underestimated in the processes taking place in enterprises. S. Borkowska (2010, p. 45) argues that "it is not clear why the role of soft factors, i.e. human resources, is not appreciated. It is a fairly common occurrence that human knowledge, creativity, openness to change, unexhausted learning skills, open communication and team collaboration are wasted [...]. The wise use of human resources in the development of innovativeness is particularly important in the absence of material and financial resources".

The ability to implement innovations, as indicated by C. Gubbins and L. Dooley (2014, p. 162), is currently becoming one of the canons of building competitiveness and of sustainable development. Organizations today must be innovative in order to work out competitive advantage in the market. This is to say they must be capable of creating innovations and implementing them. Man, as a member of the organization, plays the leading role in this process. Considering innovativeness in terms of its growth requires more focus than ever before on the staff element of the company, in line with the catchphrase "innovation by the people". The innovativeness of an enterprise is correlated with the innovativeness of its employees, meaning their ability to come up with new solutions. For an organization to develop, conscious creation of innovative work behavior is required, expressed in the pursuit of activities related to both the creation/promotion of new ideas (own or borrowed), as well as their bringing into being and implementation (Yuan, Woodman, 2010).

Employee innovation is best reflected in innovative organizations, and therefore those which encourage their employees to try out new ideas, activities (Hult, Hurley, Knight, 2004) and approaches regarding new and improved products (Luk, Yau, Sin, Tse, Chow, Lee, 2008). Innovative organizations are able to use the labor market and capital so as to bring potential innovations to fruition (Tellis, Prabhu, Chandy, 2009). In other words, innovation in an organization 
stimulates innovative behavior in employees, who can then provide new products, services or processes (Dibrell, Craig, Hansen, 2011; Hurley, Hult, 1998), given that innovativeness prompts a strong desire to move away from existing practices and stimulates engagement in exploration and experimentation. Innovativeness in a company is not limited to the emergence of new ideas, products or processes, but it also implies their active implementation. Innovativeness encourages exploration of new fields, updates the company's position in the existing domain, and provides the ability to seek new opportunities (Kyrgidou, Spyropoulou, 2013).

The aim of the study is to present the concept of measuring innovative employee behavior in the internal perspective of the organization. The above goal was achieved through literature analysis and is reflected in the layout of the content of the study. The partial least squares structural equation modeling (PLS-SEM) was selected as a method to assess the innovative behavior of employees. The article discusses how structural modeling can be used to analyze data describing innovative employee behavior. The obtained desk-research material offers a rough overview of this technique's implications and presents the potential fields of application of structural equation models. Due to the complexity of the considered constructs determining the specifics of the research model, a decision was made to apply structural equation modeling (SEM). The method enables measuring and testing the directional relationship occurring between complex multi-dimensional theoretical constructs. The structural equation model describes and empirically tests causal relationships - between manifest and latent variables identified against the backdrop of previous theoretical or partial empirical research. Unlike multivariate regression, it adopts the confirmatory, rather not exploratory, approach to raw data analysis. In addition, SEM, in contrast to multivariate regression, allows simultaneous estimation of a series of separately conducted but interrelated multiple regression equations. Importantly, the variable captured in the model can play the role of an independent and dependent variable in relation to other variables included in the model (Hair, Black, Babin, Anderson, 2014).

\section{The concept and determinants of innovative employee behavior}

Employee innovation, by analogy to organizational innovation, is understood as an ability or a tendency to generate and implement new solutions. It is expressed through innovative behaviors perceived as an unconventional, creative approach to performing tasks by modifying current and finding new, more effective and quality-guaranteeing ways of doing things. Innovative employees can identify opportunities - to modify processes, procedures, services, products, being able to find new applications for existing methods, materials or 
equipment. They can not only generate new ideas, but also come up with solutions to current problems, therefore pushing forward the development of the organization as a whole (Moghimi, Subramaniam, 2013).

Literature analysis suggests good agreement exists as to what innovative employee behavior is. The vast majority of authors point out two common themes in this respect: generating ideas (creativity) and pursuing activities related to their implementation (Głód, Kraśnicka, 2015, p. 36). Innovative behavior refers to "[...] creating or adapting ideas and their subsequent implementation, starting from the problem recognition phase, all the way down to the phase of generating ideas and solutions" (Scott, Bruce, 1994, p. 581). Some authors emphasize this may take place at various levels of the organization (Kraśnicka, Wronka-Pośpiech, 2014, p. 116). Thus, the concept of innovative behavior encompasses both creativity (generating ideas - new and useful), as well as innovativeness understood as the ability to implement innovative solutions. Accordingly, innovative behavior follows a certain pattern which can be broken down into: exploration of possibilities, generativity, formative evaluation, propagation and defense, and application (Wojtczuk-Turek, 2012, pp. 28-29). Table 1 shows selected definitions of innovative employee behavior.

Table 1. An overview of selected definitions of innovative employee behavior

\begin{tabular}{|c|c|}
\hline Author(s) & Content of definition \\
\hline $\begin{array}{l}\text { S.G. Scott and R.A. } \\
\text { Bruce (1994) }\end{array}$ & $\begin{array}{l}\text { a multi-stage process comprising two elements: creativity and } \\
\text { implementation; it is a set of behaviors which consists of: } \\
\text { generating ideas, promoting them, and implementing them }\end{array}$ \\
\hline O. Janssen (2003) & $\begin{array}{l}\text { intentional generation, promotion and implementation of new } \\
\text { ideas created by employees in the workplace/organization that } \\
\text { bring specific benefits to both the employee and the } \\
\text { organization }\end{array}$ \\
\hline $\begin{array}{l}\text { J.P.J. de } \text { Jong and } \\
\text { D.N.D. } \\
\text { (2007) }\end{array}$ & $\begin{array}{l}\text { behaviors involving activities related both to the } \\
\text { creation/proposition of new ideas, as well as their bringing into } \\
\text { being and implementation; innovation at individual level (in the } \\
\text { workplace) is perceived as initiating and intentional introduction } \\
\text { by employees (within a workplace, team or organization) of new } \\
\text { and useful ideas, processes, products or procedures }\end{array}$ \\
\hline $\begin{array}{l}\text { H. Huhtala and M.-R. } \\
\text { Parzefall, (2007) }\end{array}$ & $\begin{array}{l}\text { a complex behavior consisting of generating, promoting and } \\
\text { implementing an idea in order to achieve the organization's } \\
\text { goals in a new way }\end{array}$ \\
\hline $\begin{array}{lcc}\text { M.-R. Parzefall, } & \text { H. } \\
\text { Seeck and } & \text { A. } \\
\text { Leppänen, (2008) } & \end{array}$ & $\begin{array}{l}\text { involvement in innovative behavior, which include behaviors } \\
\text { related to the innovation process, i.e. idea generation, promotion } \\
\text { and implementation, with the aim of generating innovation }\end{array}$ \\
\hline $\begin{array}{l}\text { C. Odoardi, A. } \\
\text { Battistel and H.F. } \\
\text { Montani (2010) }\end{array}$ & $\begin{array}{l}\text { generating new and useful concepts, as well as experimenting } \\
\text { and implementing ideas in the work space }\end{array}$ \\
\hline
\end{tabular}




\begin{tabular}{|c|c|}
\hline $\begin{array}{l}\text { M.M. Hammond, } \\
\text { N.L. Neff, J.L. Farr, } \\
\text { A.R. Schwall and X. } \\
\text { Zhao (2011) }\end{array}$ & $\begin{array}{l}\text { e innovations can be broadly understood as a proc } \\
\text { ting ideas (creativity) and their implementation in } \\
\text { ing }\end{array}$ \\
\hline $\begin{array}{l}\text { S. Aryee, F.O. } \\
\text { Walumbwa, Q. Zhou } \\
\text { and Ch.A. Hartnell } \\
(2012)\end{array}$ & $\begin{array}{l}\text { innovative employees gather and use a wide range of } \\
\text { information to generate new ideas and improve existing } \\
\text { innovation processes; behaviors closely linked with the } \\
\text { employee's commitment and internal motivation }\end{array}$ \\
\hline
\end{tabular}

Source: Own elaboration based on the sources provided.

Based on the research presented in the literature, it can be assumed that innovative behavior is an intended generation, promotion and implementation of new ideas created by employees in the workplace, in the organization. Although this definition is predominant in contemporary studies, attempts have been made to further supplement it, such as that by O. Janssen (2003) who argued that these behaviors bring about specific benefits for both the employee and the organization. It is also worth emphasizing that some researchers are more concerned with the aspect of creativity, albeit they also touch upon topics associated with the implementation of creative ideas (Kraśnicka, 2016, p. 182; Carmeli, Schaubroeck, 2007).

Attention of researchers is also focused on the characteristic features of employees, which increase their propensity for innovative behavior in the workplace. Such attributes include: vigor (eagerness, zeal), dedication and commitment, as well as high energy, enthusiasm, goal-seeking, inspiration, mental resilience and persistence (Kraśnicka, Wronka-Pośpiech, 2014, p. 116; Aryee, Walumbwa, Zhou, Hartnell, 2012, p. 8;). Among the skills and attitudes most often cited in the context of employee innovation, the following stand out (Karpacz, 2016; Czapla, Świątek-Barylska, 2011, pp. 83-84;):

- creative modification of work tools and organizational procedures to perform tasks, improve work techniques and look for new improvements, innovative concepts;

- $\quad$ open-minded thinking - overcoming stereotypes and patterns, coming up with new ideas and solutions that are embedded in the company's situational context and capabilities;

- $\quad$ creating new solutions, recognizing different altenratives and possibilities for action, thinking outside the box, as well as developing, improving and enriching others' ideas;

- displaying creative behavior also towards everyday routine tasks and searching for ways to improve them, not accepting the status quo, continually questioning the work methods and showing the willingness to try out new approaches. 
Among the expected attitudes, apart from the abovementioned open-minded thinking and approach to tasks, pro-activity, focus on cooperation and sharing knowledge and experience, analysis of the way employees shows that innovativeness is indicative of the increasing importance of openness to the use of intuition and diversified thought models.

There are many factors determining the innovative behavior of employees, and they relate both to the employee themselves (subjective) as well to the organization. The subjective factors include personality traits, psychological capital, knowledge, personal skills, motivation and commitment (Aryee, Walumbwa, Zhou, Hartnell, 2012). The organizational factors, on the other hand, refer primarily to the impact of organizational culture (Martins, Terblanche, 2003) or organizational climate (Chien, Tsai-Fang, Chin-Cheh, 2013, p. 147; WojtczukTurek, 2012, pp. 79-92). The conducted literature review shows that the models of determinants of innovative employee behavior usually explore selected factors as part of the research (Table 2).

Table 2. A list of selected research models of innovative behavior

\begin{tabular}{|c|c|c|}
\hline Author & $\begin{array}{l}\text { Factors included in the model } \\
\text { (independent variables) }\end{array}$ & Dependent variables \\
\hline $\begin{array}{l}\text { E.C. Martins } \\
\text { and } \\
\text { Terblanche } \\
\text { (2003) }\end{array}$ & $\begin{array}{l}\text { strategy, structure, support mechanisms, } \\
\text { behavioral patterns encouraging } \\
\text { innovation, communication - as } \\
\text { determinants of pro-innovative } \\
\text { organizational culture }\end{array}$ & $\begin{array}{l}\text { creativity } \\
\text { innovations }\end{array}$ \\
\hline $\begin{array}{l}\text { K. Zdunczyk } \\
\text { and } \quad J . \\
\text { Blenkinsopp } \\
(2007)\end{array}$ & $\begin{array}{l}\text { dimensions of strategy, structure, support } \\
\text { mechanism, and behavioral (behavioral } \\
\text { patterns - values) }\end{array}$ & $\begin{array}{l}\text { creativity and } \\
\text { innovations as learning } \\
\text { dimensions (higher-level } \\
\text { learning) }\end{array}$ \\
\hline $\begin{array}{l}\text { S. Aryee, F.O. } \\
\text { Walumbwa, Q. } \\
\text { Zhou and Ch.A. } \\
\text { Hartnell (2012) }\end{array}$ & $\begin{array}{l}\text { transformational leadership, importance } \\
\text { of work and responsibility as viewed by } \\
\text { employees (as a direct outcome of } \\
\text { leadership), employee engagement, } \\
\text { relations between the leader and } \\
\text { subordinates (mediating variable) }\end{array}$ & $\begin{array}{l}\text { innovative behavior (and } \\
\text { how it relates to } \\
\text { performance) }\end{array}$ \\
\hline $\begin{array}{l}\text { Y. Chien, Y. } \\
\text { Tsai-Fang and } \\
\text { Y. Chin-Cheh } \\
(2013)\end{array}$ & $\begin{array}{l}\text { Organizational climate conducive to } \\
\text { innovation, knowledge sharing (a two- } \\
\text { level model, including the organizational } \\
\text { and individual level) }\end{array}$ & inn \\
\hline $\begin{array}{l}\text { Y.K. Kheng, R. } \\
\text { Mahmood and } \\
\text { S.J.H. Beris } \\
(2013)\end{array}$ & $\begin{array}{l}\text { pro-innovative organizational climate, } \\
\text { relations between the leader and } \\
\text { subordinates, social capital }\end{array}$ & $\begin{array}{l}\text { innovative behavior at } \\
\text { work }\end{array}$ \\
\hline Wojtczuk-Turek & pro-innovative & innovative behawior at \\
\hline
\end{tabular}




\begin{tabular}{|l|l|l|}
\hline (2012) & $\begin{array}{l}\text { organizational culture, leader's behavior } \\
\text { (leadership), organizational commitment }\end{array}$ & work \\
& $\begin{array}{l}\text { factors, practices in human capital } \\
\text { management, barriers to innovation }\end{array}$ &
\end{tabular}

Source: own study based on: Kraśnicka, Wronka-Pośpiech, 2014; Wojtczuk-Turek, 2012; Chien, Tsai-Fang, Chin-Cheh, 2013; Kheng, Mahmood, Beris, 2013; Aryee, Walumbwa, Zhou, Hartnell, 2012; Zdunczyk, Blenkinsopp, 2007; Martins, Terblanche, 2003.

Empirical studies of determinants of innovative behavior confirm that it is influenced by both subjective factors (e.g. competences, psychological capital, personality traits, or expected performances (Wojtczuk-Turek, 2012, p. 169) and organizational ones. Among the latter, a strong impact on organizational behavior is exerted by pro-innovative organizational culture (Wojtczuk-Turek, 2012, p. 169) or different dimensions of leadership (Kraśnicka, Wronka-Pośpiech, 2014, pp. 118-119; Aryee, Walumbwa, Zhou, Hartnell, 2012, pp. 11-12).

An example of a comprehensive set of determinants of creativity and innovation is a model proposed by E.C. Martins and F. Terblanche (2003, p. 70), which accounts for strategy, support mechanisms, behavioral patterns encouraging innovation, and communication. In the 1990s, research on individual innovative behaviors of employees identified the following determinants: leadership, team relations, individual characteristics such as problem-solving styles and a psychological climate conducive to innovation (Scott, Bruce, 1994). In later studies covering the team and individual level, the features of work teams were taken into account, including e.g. diversity of qualifications, skills (Camelo-Ordaz, Fernández-Alles de la Luz, Martínez-Fierro, 2006). In what concerns the most recent research in this area, the influence of leaders and leadership on innovative employee behavior (including transformational leadership, importance of work and responsibility as viewed by employees, employee engagement, relations between the leader and subordinates) are also considered (Głód, Kraśnicka, 2015, p. 38; Aryee, Walumbwa, Zhou, Hartnell 2012; de Jong, Hartog 2007).

The cited research results confirm the complexity of determinants of innovative employee behavior, pointing to the need to look for multidimensional tools to measure employee innovation. One of the methodological challenges for researchers in this field is to ensure the reliability of research findings based on a subjective (and currently predominant) measurement methodology (Blindenbach-Driessen, Van Dalen, Van Den Ende, 2010). Proper measurement of the phenomena under consideration is pivotal for meeting the basic requirements of the methodological rigor of the conducted research (Czakon, 2014) and a prerequisite for eventual reliability and validity of results, and by extension, for the quality of the knowledge created (Venkatraman, Grant, 1986). 


\section{Application of structural equation modeling to assess innovative employee behavior}

While the definition of the concept of innovative employee behavior does not raise too many reservations, its measurement alone is no longer so unambiguous. Due to its complex nature, this construct requires application of the structural equation modeling methodology (Klimas, 2019; SwiatowiecSzczepańska, 2015; Bedyńska, Książek, 2012).

It is assumed that the proper preparation of tests is the most important stage of the research procedure (Hinkin, Tracey, Enz, 1997; Venkatraman, Grant, 1986). Methodological requirements for the outline of the research process determine the quality, reliability and validity of both the research itself and the collected empirical material, and hence - of results derived from analyses, of formulated interpretations, and of the conclusions drawn on their basis. It is worth noting that the aspects concerning methodological rigor (Czakon, 2015) were not the only reason for initiating a more profound discussion or providing a more thorough description of the methodological choices, nor the effects of these choices. A methodical description of the research procedure and its subsequent components is also the basis for the possibility of undertaking replication research, which is of immense value to the verification of newly created knowledge, since, as aptly put by K.R. Popper, "singular, individual events [note: empirical studies] are of no meaning to science" (1977, p. 74).

The scales developed by Y. Khar Kheng, R. Mahmood, S.J. Hamy Beris (2013) and F. Yuan, R.W. Woodman (2010) will be used to study the level of innovative behavior in employees. Based on literature analysis, it was assumed that individual innovation in employees is a multidimensional construct made up of two dimensions: (1) intentions (wishes, desires) of employees regarding innovative intention: innovation propensity, involvement in company growth, creativity and empowerment, willingness to take challenges and risks; (2) an innovative work environment that provides the necessary support for implementing innovations: an organizational culture supporting innovativeness, i.e. ensuring the availability of resources and the ability to translate ideas into business ventures, encouraging taking risks, creating and sharing knowledge, marked by autonomy and cooperation; support from managers - assistance in the implementation of ideas, friendly leadership, mentoring. In addition, the structure of these dimensions allows to separate two subcategories of a pro-innovative approach in employees: the generation and the implementation of ideas that favor innovativeness.

The research assumes that both variables co-creating the conceptual research model are multidimensional latent variables that are directly immeasurable. However, individual questions included in the measurement questionnaire will be 
recognized as single, objective, observable and measurable indicators for a given unobservable variable.

Typical for economic research, the reflective nature of the correlations between measurable and latent variables indicates that specific latent variables are a reflection of the sets of measurement indicators identified for them. The proposed operationalization is the result of exploratory investigations, hence it is necessary to test the validity of the measurement assumptions adopted in it.

To evaluate the research model, the partial least squares path model using raw data from the PLS-PM was selected. This method is considered to be a "soft" alternative to traditional structural equation modeling (SEM) and it allows to overcome excessively restrictive assumptions related to variable distributions and key problems of the model's theoretical specification (Sagan, 2018; Hair, Sarstedt, Pieper, Ringle, 2012). The PLS-PM is less restrictive in terms of assumptions than the traditional SEM. In particular, the PLS-PM enables analysis of more complex models with a greater number of latent or measurement variables in relation to the number of observations (Assaker, Hallak, Vinzi, O’Conner, 2013).

Given the above, the point of departure for the model is: (1) to determine the linear correlations of latent variables (here: employee intentions regarding innovative behavior and innovative work environment), (2) to assign latent variables to observable variables describing their level and determining the nature of the latter.

Parameter estimation for the PLS-PM model will concern estimation of the parameters of the measurement (external) and structural (internal) model. The internal model describes the relationships occurring between the latent variables, while the external model described the relationships between the latent variables and the observable variables describing their level. The internal model will have the form of a system of econometric equations, while the external model will consists of two correlations: ratio (weight) and reflection (mirror). The ratio correlation allows estimating the level of unobservable variables, while the reflection correlation measures the level of reflection of individual latent variables against their respective observable variables. The study assumes that all variables assigned to particular latent variables are reflective (Paliszkiewicz, 2019).

The iterative method of the PLS will be used to estimate the parameters defined in the correlation model. The results obtained from estimating the level of latent variables will be used to estimate the parameters of the internal model. To this end, the Classical Least Squares Method (CLSM) will be used, in which individual equations are treated as single regressions. Parameters of the reflection correlation will also be estimated using this method. Having said that, the CLSM does not assume the independence of observable variables or their distribution, nor does it assume the distribution of the random component. Lastly, there are 
also no restrictions as to the size of the sample or the scale of the measurement (Vinzi, Trinchera, Amato, 2010; Gatnar, 2003; Rogowski, 1990).

Testing the quality of the model is a very important part of its design, hence the following aspects will be evaluated (Osińska, 2014, p. 74): the quality of the external model, the quality of the internal model, the model as a whole, the significance of parameter estimation. Obtaining a good quality model is not perceived as a proof, but rather as a confirmation that the presumed correlations may indeed arise (Osińska, 2014, p. 74). The quality of the external model is evaluated based on the measures of reliability and validity as well as the homogeneity of the scale. Meanwhile, evaluation of the reliability of variable selection is made on the basis of Cronbach's alpha, Dijkstra-Henseler's rho and Jöreskog's rho. All quality indicators assume values within the range [0;1]. If all variables assigned to a latent variable are not mutually correlated, then the above measures assume zero values. If all variables are perfectly correlated, the measures take values equal to one. It is assumed that the variable set assigned to a latent variable is reliable if the values of the above measures are greater than 0.7 (Paliszkiewicz, 2019).

Convergent and discriminant validity are tested by the AVE measure (where AVE stands for average variance extracted) and the Fornell-Lacker criterion, respectively. The AVE determines the average percentage of variance of individual observable variables, explained by the latent variable they describe. This measure evaluates only the quality of individual reflective correlations. Values above 0.5 indicate the level of common variance, appropriate for reflective indicators (Bagozzi, Yi, 1988). In the Fornell-Lacker criterion, discriminant validity is confirmed when the medians of the separated variance are higher than the coefficients of correlation with other latent variables.

Last but not least, significance of the parameters is evaluated. However, the use of the PLS-SEM method makes it impossible to use traditional statistical tests for this purpose. In the literature, methods based on resampling schemes can be found, allowing to determine the approximate significance of variables in a model. These include the bootstrap technique and the jackknife technique.

\section{Conclusion}

Structural Equation Modeling, and especially its more recent version PLS-SEM, is being increasingly used for data analysis in economics. It is certainly worth encouraging researchers to apply this statistical technique more widely, as it provides more opportunities than the traditional methods, especially when it comes to constructing and testing complex models of innovative employee behavior. Structural Equation Modeling is gradually replacing conventional statistical techniques, such as correlation analysis, regression analysis or median 
equality tests (e.g. analysis of variance, ANOVA), whose main disadvantage is the lack of comprehensive causative modeling. Structural modeling, on the other hand, enables the designing of models that account for latent (unobservable) variables, formative variables, indirect outcomes and inter-group comparisons (Lowry, Gaskin, 2014). It should be emphasized that the starting point for the application of structural modeling should always be a theory assuming the existence of specific correlations between analyzed variables (Bedyńska, Książek, 2012). Models for innovative employee behavior are too complex to be studied by traditional statistical techniques. As a consequence, many researchers are limited to testing only small components of these models, instead of obtaining a full picture of the underlying theory. Another advantage of structural modeling, as compared to traditional statistical techniques, is the possibility of including latent variables in the model, meaning constructs resulting from the summary of several statements contained in the questionnaire (observable variables). What additionally speaks in favor of the SEM is the ability to simultaneously test indirect (mediation analysis) and direct correlations between a large group of variables. This makes it possible to estimate not only simple correlations, but also to analyze the strength of one variable's influence on another (similarly to regression analysis) (Kacprzak, 2018). In traditional statistical techniques, reliability and validity of a research tool must be assessed separately before proceeding to proper analysis. Structural modeling, meanwhile, allows for simultaneous evaluation of a research tool (measurement model) and of a theory being tested (structural model). This is all the more important since the high validity of a single scale may differ from the theory when measured separately and in isolation, if other scales referring to the same theory were used in its measurement.

All these advantages of structural equation modeling are of particular importance to researchers tackling the many different topics of behavioral sciences, an example of which is innovative employee behavior. In such research, complex correlations between variables and measurement barriers often arise.

\section{References}

Aryee, S., Walumbwa, F.O., Zhou, Q., Hartnell, Ch.A. (2012). Transformational Leadership, Innovative Behavior, and Task Performance: Test of Mediation and Moderation Processes. Human Performance, 25(1), 1-25. DOI: http://dx.doi.org/10.1080/08959285.2011.631648.

Assaker, G., Hallak, R., Vinzi, V.E., O'Conner, P. (2013). An Empirical Operationalization of Countries' Destination Competitiveness Using Partial Least Squares Modeling. Journal of Travel Research, 53(1), 26-43. DOI: 10.1177/0047287513481275. 
Bagozzi, R.P., Yi, Y. (1988). On the Evaluation of Structural Equation Models. Journal of the Academy of Marketing Sciences, 16(1), 74-94. DOI: http://dx.doi.org/10.1007/BF02723327.

Bedyńska, S., Książek, M., (2012). Statystyczny drogowskaz: praktyczny przewodnik wykorzystania modeli regresji oraz równań strukturalnych. Warszawa: Wydawnictwo Akademickie SEDNO.

Blindenbach-Driessen, F., Van Dalen, J., Van Den Ende, J. (2010). Subjective Performance Assessment of Innovation Projects. Journal of Product Innovation Management, 27(4), 572-592.

Borkowska, S. (2010). ZZL dźwignią innowacyjności przedsiębiorstw. In: S. Borkowska (ed.), Rola ZZL w kreowaniu innowacyjności organizacji (38-63). Warszawa: Difin.

Bratnicka, K., Ingram, T., Wronka-Pośpiech, M. (2016). Rozwikłanie zależności pomiędzy klimatem organizacyjnym a innowacyjnymi zachowaniami organizacyjnymi [Untangling the Relationship Between the Organizational Climate and Innovative Organizational Behaviour]. Zeszyty Naukowe Uniwersytetu Prayrodniczo-Humanistycznego w Siedlcach. Administracja i Zarzadzanie (38), 111, 213 225.

Camelo-Ordaz, C., Fernández-Alles de la Luz, M., Martínez-Fierro, S. (2006). Influence of top management team vision and work team characteristics on innovation: The Spanish case. European Journal of Innovation Management, 9(2), 179-201. DOI: https://doi.org/10.1108/14601060610663569.

Carmeli, A., Schaubroeck, J. (2007). The influence of leaders' and other referents' normative expectations on individual involvement in creative work. The Leadership Quarterly, 18(1), 35-58. DOI:10.1016/j.leaqua.2006.11.001.

Chien, Y., Tsai-Fang, Y., Chin-Cheh, Y. (2013). Knowledge Sharing, Organizational Climate, and Innovative Behavior: A Cross-level Analysis of Effects. Social Behavior and Personality, 41(1), 143-156. DOI: http://dx.doi.org/10.2224/sbp.2013.41.1.143.

Czakon, W. (2014). Kryteria oceny rygoru metodologicznego badań w naukach o zarządzaniu [Criteria for rigor evaluation in management research]. Organizacja $i$ Kierowanie, nr 161(1), 51-62.

Czakon, W. (2015). Rygor metodologiczny. In: W. Czakon (ed.), Podstany metodologii badań naukowych o zarzadzaniu (82-102). Warszawa: Wolters Kluwer Business.

Czapla, T., Świątek-Barylska, I. (2011). Znaczenie innowacyjności w świetle badań wartości i systemów kompetencyjnych organizacji [Significance of Innovation in the Light of Research on the Value and Competences Systems of Organizations]. Wspótczesne Zarzqudzanie, 3, 80-87.

de Jong, J.P.J., Hartog, D.N.D. (2007). How leaders influence employee's innovative behavior. European Journal of European Management, 10(1), 41-64. DOI 10.1108/14601060710720546.

Dibrell, C., Craig, J., Hansen, E. (2011). Natural Environment, Market Orientation, and Firm Innovativeness: An Organizational Life Cycle Perspective. Journal of Small Business Management, 49(3), 467-489.

Gableta, M., Bodak, A. (2014). Koncepcja zarządzania zasobami ludzkimi z perspektywy wzrostu innowacyjności pracowników [Human Resources Management Concept 
in Terms of an Increase in Innovativeness of Employees]. Zeszyty Naukowe Małopolskiej Wyższej Szkoly Ekonomicznej w Tarnowie. Prace z zakresu zarzadzania, $t$. 24(1), 95-102.

Gatnar, E. (2003). Statystyczne modele struktury prayczynowej zjawisk ekonomicznych [Statistical models of the causal structure of economic phenomena]. Katowice: Wydawnictwo Akademii Ekonomicznej.

Głód, G., Kraśnicka, T. (2015). Zachowania innowacyjne pracowników w MŚP - wyniki badań [Innovative Behavior of Workers the SMEs - Results]. Studia Ekonomiczne Uniwersytetu Ekonomicznego w Katowicach, 212, 35-51.

Gubbins, C., Dooley, L. (2014). Exploring Social Network Dynamics Driving Knowledge Management for Innovation. Journal of Management Inquiry, 23(2), 162-185. DOI: $10.1177 / 1056492613499203$.

Hair, J.F., Sarstedt, M., Pieper, T.M., Ringle, C.M. (2012). The Use of Partial Least Squares Structural Equation Modeling in Strategic Management Research: A Review of Past Practices and Recommendations for Future Applications. Long Range Planning, 45, 320-340. http://dx.doi.org/10.1016/j.lrp.2012.09.008.

Hair, J.H., Black, W.C., Babin, B.J., Anderson, R.E. (2014). Multivariate Data Analysis. Seventh Edition. Edinburgh: Pearson Education Limited.

Hammond, M.M., Neff, N.L., Farr, J.L., Schwall, A.R., Zhao, X. (2011). Predictors of Individual-Level Innovation at Work: A Meta-Analysis. Psychology of Aesthetics, Creativity, and the Arts, 5(1), 90-105. DOI: 10.1037/a0018556.

Hinkin, T.R., Tracey, J.B., Enz, C.A. (1997). Scale Construction: Developing Reliable and Valid Measurement Instruments. Journal of Hospitality \& Tourism Research, 21(1), 100-120.

Huhtala, H., Parzefall, M.-R. (2007). A Review of Employee Well-Being and Innovativeness: An Opportunity for a Mutual Benefit. Creativity and Innovation Management, 16(3), 299-306. DOI:10.1111/j.1467-8691.2007.00442.x.

Hult, G.T.M., Hurley, R.F., Knight, G.A. (2004). Innovativeness: Its antecedents and impact on business performance. Industrial Marketing Management, 33, 429- 438.

Hurley, R.F., Hult, G.T.M. (1998). Innovation, Market Orientation, and Organizational Learning: An Integration and Empirical Examination. Journal of Marketing, 62(3), $42-54$.

Ingram, T. (2016). Związki pomiędzy niepewnością dotyczącą zadań, zaangażowaniem i zachowaniami innowacyjnymi w miejscu pracy. Model teoretyczny Relationships Between Task Uncertainty, Employee Commitment and Innovative Behaviors in the Workplace: Theoretical Model]. Studia Ekonomiczne Uniwersytetu Ekonomicznego w Katowicach. Zarzqdzanie, 278(7), 42-52.

Ingram, T., Głód, W. (2014). Zależności pomiędzy satysfakcja pracy a organizacyjnymi zachowaniami innowacyjnymi pracowników branży IT [Relationships between Job Satisfaction and Organizational Innovative Behaviors]. Przeglad Organizacji, 12, 16-21.

Janssen, O. (2003). Innovative behavior and job involvement at the price of conflict and less satisfactory relations with co-workers. Journal of Occupational and Organizational Psychology, 76(3), 347-364. 
Janssen, O. (2005). The joint impact of perceived influence and supervisor supportiveness on employee innovative behaviour. Journal of Occupational \& Organizational Psychology, 78(4), 573-579.

Kacprzak, A. (2018). Modelowanie strukturalne w analizie zachowań konsumentów: porównanie metod opartych na analizie kowariancji (CB-SEM) i częściowych najmniejszych kwadratów (PLS-SEM) [Structural Equation Modelling in the Consumer Behaviour Analysis: the Comparison of Covariance-Based (CB-SEM) and Partial Least Square (PLS-SEM) Methods]. Handel Wewnetrzny, 6(377), 247261 (tom I).

Karpacz, J. (2016). Antecedencje innowacyjności jako wymiaru orientacji przedsiębiorczej na poziomie indywidualnym [Antecedents of Innovativeness as The Dimension of The Entrepreneurial Orientation on The Individual Level]. Prace Naukowe Uniwersytetu Ekonomicznego we Wroctawiu, 444, 231-240.

Kheng, Y.K., June, S., Mahmood, R. (2013). The Determinants of Innovative Work Behavior in the Knowledge Intensive Business Services Sector in Malaysia. Asian Social Science, 9(15), 47-59.

Kheng, Y.K., Mahmood, R., Beris, S.J.H. (2013). A Conceptual Review of Innovative Work Behavior in Knowledge Intensive Business Services among Knowledge Workers in Malaysia. International Journal of Business, Humanities and Technology, 3(2), 91-99.

Klimas, P. (2019). Relacje współtworz̨enia innowacji w ekosystemach. Kontekst ekosystemu gamingowego. Warszawa: Wydawnictwo C.H.Beck.

Kraśnicka, T. (2016). Działania kadry menedżerskiej zorientowane na stymulowanie innowacyjności pracowników w MŚP [Management Practices Aiming to Stimulate SME Employee Innovativeness]. Studia Ekonomiczne Uniwersytetu Ekonomicznego w Katowicach. Zarzqdzanie, 278(7), 53-66.

Kraśnicka, T., Głód, W. (2015). Poziom innowacyjności kadry kierowniczej najwyższego szczebla w polskich przedsiębiorstwach [Level of the Innovativeness of Top Management in Polish Enterprises]. Studia Ekonomiczne Uniwersytetu Ekonomicznego w Katowicach, 212, 70-90.

Kraśnicka, T., Ingram, T. (2016). Rola przywództwa transformacyjnego w kształtowaniu zachowań innowacyjnych pracowników [The Role of Transformational Leadership in Shaping Employee Innovative Behaviors]. Prace Naukowe Uniwersytetu Ekonomicznego we W roctawiu, 422, 181-192.

Kraśnicka, T., Wronka-Pośpiech, M. (2014). Stymulowanie zachowań innowacyjnych pracowników w korporacjach [Stimulating Innovative Behavior of Employees in Corporations]. Studia Ekonomiczne Uniwersytetu Ekonomicznego w Katowicach, 183(1), 115-129.

Krot, K. (2014). Determinanty indywidualnych zachowań innowacyjnych w perspektywie młodszych i starszych pracowników [Determinants of Individual Innovative Behaviors in the Perspective of Younger and Older Workers]. Przedsiebiorczosic $i$ Zarzqdzanie, 15(11)(1), 221-231.

Kyrgidou, L.P., Spyropoulou, S. (2013). Drivers and Performance Outcomes of Innovativeness: An Empirical Study. British Journal of Management, 24, 281-298. DOI: $10.1111 /$ j.1467-8551.2011.00803.x. 
Lowry, P.B., Gaskin, J. (2014). Partial Least Squares (PLS) Structural Equation Modeling (SEM) for Building and Testing Behavioral Causal Theory: When to Choose It and How to Use It. IEEE Transactions on Professional Communication, 57(2), 123146.

Luk, C.-L., Yau, O.H.M., Sin, L.Y.M., Tse, A.C.B., Chow, R.P.M., Lee, J.S.Y. (2008). The effects of social capital and organizational innovativeness in different institutional contexts. Journal of International Business Studies, 39(4), 589-612.

Martins, E.C., Terblanche, F. (2003). Building organisational culture that stimulates creativity and innovation. European Journal of Innovation Management, 6(1), 64-74. DOI: https://doi.org/10.1108/14601060310456337.

Moghimi, S., Subramaniam, I.D. (2013). Employees' Creative Behavior: The Role of Organizational Climate in Malaysian SMEs. International Journal of Business and Management, 8(5), 1-12.

Nederveen Pieterse, A., van Knippenberg, D., Schippers, M., Stam, D. (2010). Transformational and transactional leadership and innovative behavior: The moderating role of psychological empowerment. Journal of Organizational Behavior, 31(4), 609-623.

Odoardi, C., Battistel, A., Montani, H.F. (2010). Can goal theories explain innovative work behaviour? The motivating power of innovation-related goals. Bollettino Di Psicología Applicata, 261-262, 3-17.

Osińska, M. (2014). Pomiar $i$ ocena efektywności wykorzystania kapitalu intelektualnego województw w Polsce [doctoral thesis]. Poznań: Uniwersytet Ekonomiczny w Poznaniu.

Paliszkiewicz, J. (2019). Praywództwo, zaufanie $i$ zarz̨qdzanie wiedzq $w$ innowacyjnych przedsiębiorstwach. Warszawa: CeDeWu.

Parzefall, M.-R., Seeck, H., Leppänen, A. (2008). Employee innovativeness in organizations: a review of the antecedents. Finnish Journal of Business Economics, 2, 165-182.

Ployhart, R.E. (2015). Strategic Organizational Behawior (STROBE): The Missing Voice in the Strategic Human Capital Conversation. Academy of Management Perspectives, 29(3), 342-356.

Popper, K.R. (1977). Logika odkrycia naukowego [The Logic of Scientific Discovery]. Warszawa: Państwowe Wydawnictwo Naukowe.

Rogowski, J. (1990). Modele miekkeie. Teoria i zastosowanie w badaniach ekonomicznych. Białystok: Dział Wydawnictw Filii UW w Białymstoku.

Sagan, A. (2018). Analiza ścię̧kowa w badaniach marketingowych. Kraków: Wydawnictwo Uniwersytetu Ekonomicznego w Krakowie.

Sameer, Y.M. (2018). Innovative behavior and psychological capital: Does positivity make any difference? Journal of Economics \& Management. University of Economics in Katowice, 32(2), 75-101.

Scott, S.G., Bruce, R.A. (1994). Determinants of Innovative Behavior: A Path Model of Individual Innovation in theWorkplace. Academy of Management Journal, 37(3), 580-607. 
Światowiec-Szczepańska, J. (2015). Zaawansowane testowanie model badawczych. In: W. Czakon (ed.), Podstany metodologii badań naukonych o zarzadzaniu (199-227). Warszawa: Wolters Kluwer Business.

Tellis, G.J., Prabhu, J.C., Chandy, R.K. (2009). Radical Innovation Across Nations: The Preeminence of Corporate Culture. Journal of Marketing, 73(1), 3-23.

Turek D., Wojtczuk-Turek, A. (2017). How Destructive Social Aspects Inhibit Innovation in the Organisation. International Journal of Contemporary Management, 16(2), 267-294.

Venkatraman, N., Grant, J.H. (1986). Construct Measurement in Organizational Strategy Research: A Critique and Proposal. Academy of Management Review, 11(1), 71-87.

Vinzi, V.E., Trinchera L., Amato, S. (2010). PLS Path Modeling: From Foundations to Recent Developments and Open Issues for Model Assessment and Improvement. In: V.E. Vinzi, W.W. Chin, J. Henseler, H. Wang (eds.), Handbook of Partial Least Squares: Concepts, Methods and Applications (42-82). Berlin: Springer Handbooks of Computational Statistics.

Wojtczuk-Turek, A. (2012). Zachowania innowacyjne w pracy. Wybrane zagadnienia teoretyczne $i$ praktyczne. Warszawa: Difin.

Yuan, F., Woodman, R.W. (2010). Innovative behavior in the workplace: the role of performance and image outcome expectations. Academy of Management Journal, 53(2), 323-342.

Zdunczyk, K., Blenkinsopp, J. (2007). Do organisational factors support creativity and innovation in Polish firms? European Journal of Innovation Management, 10(1), 2540. DOI 10.1108/14601060710720537. 